\title{
Spontaneous pneumoperitoneum with subcutaneous emphysema
}

\author{
Ryan T Lewinson, ${ }^{1}$ Rebecca E Lewinson, ${ }^{2}$ Peter $S$ Graves ${ }^{2}$
}

${ }^{1}$ University of Calgary Cumming School of Medicine, Calgary, Alberta, Canada ${ }^{2}$ Queensway Carleton Hospital, Ottawa, Ontario, Canada

\section{Correspondence to} Dr Ryan T Lewinson, lewinson@ucalgary.ca

Accepted 16 June 2016
CrossMark

To cite: Lewinson RT, Lewinson RE, Graves PS. BMJ Case Rep Published online: [please include Day Month Year] doi:10.1136/ bcr-2016-215815

\section{DESCRIPTION}

An 85 -year-old woman without recent history of surgery or trauma was referred to the emergency department (ED) by her family physician on identifying pneumoperitoneum on chest radiograph. At presentation, the patient's vital signs were stable and normal. The patient described feeling bloated with generalised mild-moderate abdominal pain, and had no respiratory concerns. On physical examination, the patient had a soft abdomen that was non-tender to percussion or palpation. There was neither rebound tenderness nor guarding and bowel sounds were heard throughout the abdomen. Chest radiograph in the ED confirmed pneumoperitoneum (figure 1), without presence of pneumothorax or pneumomediastinum.

CT confirmed moderate pneumoperitoneum, but failed to identify an abdominal or pelvic cause (figure 2). No evidence of obstruction or perforation was seen along the gastrointestinal tract and no evidence of fluid collection was found; however, subcutaneous emphysema was identified in the epigastric region.

In pneumoperitoneum, CT represents an important test to rule out gastrointestinal perforation. ${ }^{1}$ When gastrointestinal causes of pneumoperitoneum are not observed, and the patient's presentation is inconsistent with perforation, thoracic or pelvic causes may be suspected. ${ }^{2}$ In cases such as ours, the abnormal finding of subcutaneous emphysema in the epigastric region may suggest a possible thoracic cause, as air may flow along bronchovascular sheaths into subcutaneous tissues and into the

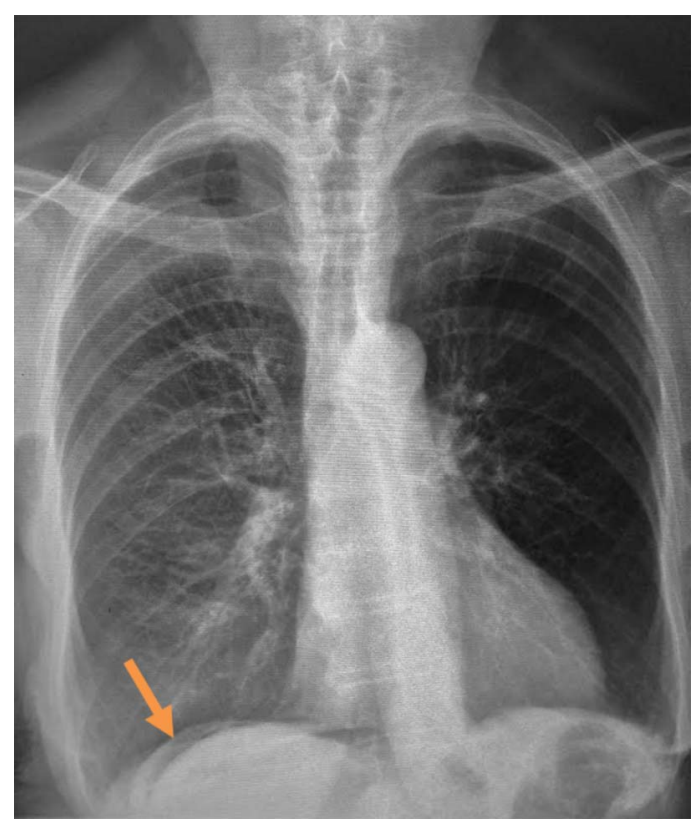

Figure 1 Chest radiograph showing free air under the right hemidiaphragm (arrow).

abdomen, producing subcutaneous emphysema and pneumoperitoneum. ${ }^{3}$ However, in our case, thoracic causes were not found on imaging nor on clinical examination.

After consulting the surgical team, the final diagnosis of spontaneous pneumoperitoneum was made, and the patient was discharged for non-operative management.

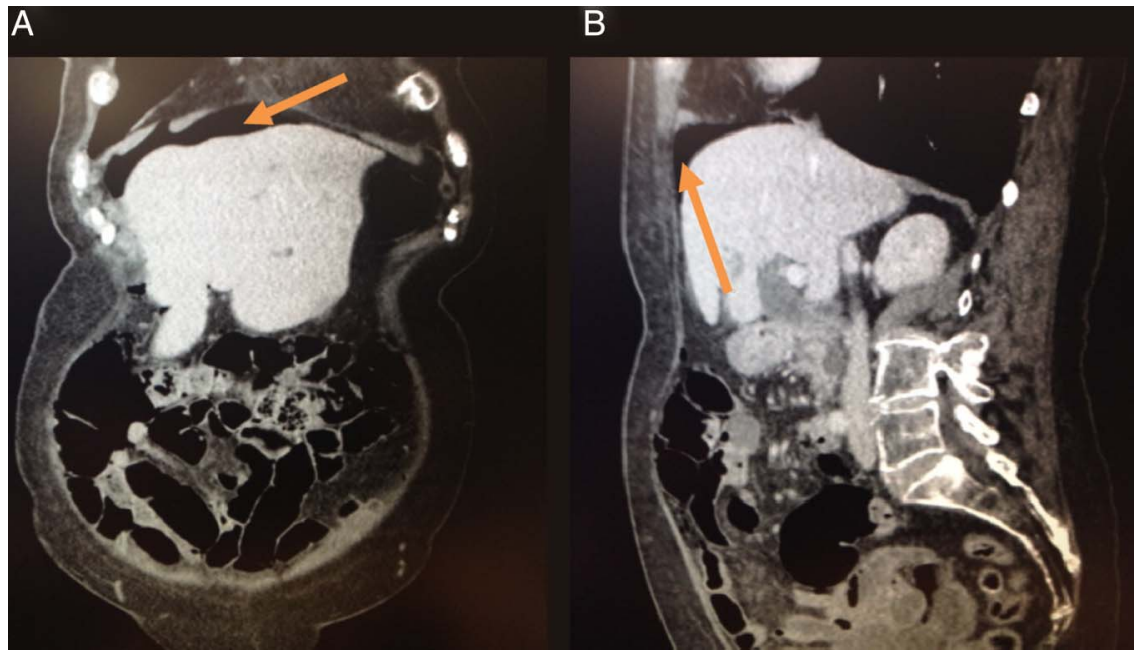

Figure 2 (A) Frontal plane and (B) sagittal plane CT showing pneumoperitoneum. Neither an abdominal nor a pelvic cause of pneumoperitoneum can be seen. 


\section{Learning points}

- Spontaneous pneumoperitoneum can be present with a relatively unremarkable physical examination.

- When neither abdominal nor pelvic causes of pneumoperitoneum are found, investigations into thoracic causes can be performed.

- Pneumoperitoneum does not always necessitate surgical intervention.

Contributors PSG was the attending physician in the case. RTL and REL were involved in the case. RTL and REL drafted the manuscript and PSG reviewed the manuscript. All the authors approved the final version. RTL and REL contributed equally.

Competing interests None declared.

Patient consent Obtained.

Provenance and peer review Not commissioned; externally peer reviewed.

\section{REFERENCES}

1 Borofsky $\mathrm{S}$, Taffel $\mathrm{M}$, Khati $\mathrm{N}$, et al. The emergency room diagnosis of gastrointestinal tract perforation: the role of CT. Emerg Radiol 2015;22:315-27.

2 Williams NM, Watkin DF. Spontaneous pneumoperitoneum and other non-surgical causes of intraperitoneal free gas. Postgrad Med J 1997;73:531-7.

3 Boersma WG, Teengs JP, Postmus PE, et al. An unusual cause of subcutaneous emphysema, pneumomediastinum and pneumoperitoneum. Eur Respir $J$ 1988;1:969-71.

Copyright 2016 BMJ Publishing Group. All rights reserved. For permission to reuse any of this content visit http://group.bmj.com/group/rights-licensing/permissions.

BMJ Case Report Fellows may re-use this article for personal use and teaching without any further permission.

Become a Fellow of BMJ Case Reports today and you can:

- Submit as many cases as you like

- Enjoy fast sympathetic peer review and rapid publication of accepted articles

- Access all the published articles

- Re-use any of the published material for personal use and teaching without further permission

For information on Institutional Fellowships contact consortiasales@bmjgroup.com

Visit casereports.bmj.com for more articles like this and to become a Fellow 